\title{
A Sociolinguistic Analysis of Hedging in Facebook Comments: A Sex- and Age-based Approach
}

\author{
Sarab kadir Mugair ${ }^{1 *}$, Inst. Atyaf Hasan Ibrahim², Amthal Mohammed Abbas ${ }^{1}$ \\ ${ }^{1}$ College of Basic Education, University of Diyala, Iraq \\ ${ }^{2}$ College of Education for Human Sciences, University of Diyala, Iraq \\ Corresponding Author: Sarab kadir Mugair, E-mail: sarabkadir@gmail.com
}

\begin{tabular}{l} 
ARTICLE INFO \\
\hline Article history \\
Received: July 02, 2018 \\
Accepted: November 13, 2018 \\
Published: December 01, 2018 \\
Volume: 7 Issue: 7 \\
Advance access: October 2018 \\
Special Issue on Language \& \\
Literature \\
\hline
\end{tabular}

Conflicts of interest: None

Funding: None

\begin{abstract}
The study investigates the effect of sex and age on the use of hedges in Facebook comments. The sample of the study consists of 300 comments written by native male and female Facebook users as their reflections to the same posts. The procedures followed in this study cover the discussion of the phenomenon and then its relation to world of social media. Then, an analysis of the posts of the sample of the study is tackled. The analysis aims at exploring whether the variables, sex and age, are traceable in reflecting the ways by which male and female language users can give their stances via hedging in Facebook comments. Hyland's (2005) model is adopted in the process of analysis. The findings uncovered that there are fundamental contrasts with respect to sex and age in the area of hedging; female users make more use of hedges than male do in addition to the idea that the older one grows, the more use of hedges is.
\end{abstract}

Key words: Hedges, Sex, Age, Facebook Comments

\section{INTRODUCTION}

In the last several decades, the topic of hedging has attracted an increasing attention on the part of researchers, especially from those of scientific and academic writing. In general, the use of hedges plays a major role in discourse, especially in social media like Facebook and is a vital means of presenting the writers' stances via their writings (Hyland, 1998:6-15; Hewings, 2006:17), which are considered as a social genre employed as a communicative method among members of a specific discourse community (Bruce, 2005). To this study, social media, through Facebook, varies in its presentation of the writers' stances via their writings and this variety belongs to the gender differences.

In fact, men and women differ in the use of language discourse and this difference has been of big interest for many discourse scholars. Nowadays, there has been great care of research on the nature and existence of differences between men and women through the use of hedges in their language especially in their writings. As a matter of consensus, gender differences have also become an important issue in the study of linguistics. On the other hand, Weatherall (2002:54) argues that there are important relationships between language and gender. Likewise, Tannen (1990:76) claims that women speak and hear a language of connection and intimacy while men speak and hear a language of status and independence. Thus, research, on gender in general and hedging in particular, has mostly attracted Lakoff in her book "Language and Women's Place" (1975). Lakoff (ibid:81) states that women's speech misses authority and this is because, to be "feminine", women must learn to acquire an unassertive style of communication. To her, the phrase "women's language" is used to refer to a group of linguistic devices that act this function, including hesitations, tag questions, intensive adverbs, compound requests, empty adjectives and also hedges.

Thus, hedging is a term used to refer to the expression of tentativeness and possibility in language use and is definitive to scientific writing and academic discourse (Hyland, 1996a; Rounds, 1982) which enables writers to show their stances in their writings and whether their stances are affected by their gender and age or not. Hyland (1996a:433) adds "hedges allow writers to anticipate possible oppositions by expressing their statements with caution". He continues to say that no doubt the use of hedges is affected by the gender and age of the writers.

However, the focus of the present study is on showing to what extent the use of hedging is traceable in writing, and if this trace is affected by the writers' gender and age. As mentioned previously, the study adopts Hyland's model (2000) to achieve its aims. The data comprises 300 Facebook comments that are selected randomly from online net.

\section{THE NATURE OF HEDGING}

Bonyadi, et al. (2012: 1186) state that it is difficult to give a clear definition of hedging as it has been presented from different perspectives by different scholars for ages. Thus, the concept of hedging is regarded as "any linguistic means used to indicate either (a) a complete commitment to the true value of an accompanying proposition, or (b) a desire not to express that commitment categorically" Hyland (1998:1). To 
Hyland (ibid) hedges are viewed as a means by which writers can show a proposition as an attitude or sensible reasoning rather than a fact or definite knowledge in order to avoid the responsibility that can be output from the certainty of a proposition. As a result to what mentioned above, Hyland (2005:130) in particular categorizes hedges according to three functions: (i) decreasing force of statements by using specific adverbs, e.g., almost, fairly, partly, etc.; (ii) making statements indefinite by means of frequency adverbs, e.g., usually, sometimes; and (iii) reducing responsibility for truth with the use of probably, perhaps, or may.

Similarly, Salager-Meyer (1994:150) remarks two major purposes for the use of hedging. First: to denote helpful tentativeness and vagueness and to make sentences more acceptable to the hearer/reader via using understatements, and thus to decrease the danger of negation. Lakoff (1973:77), indeed, points out that any utterance or a sentence can be true to a certain degree and false to another degree, i.e., true in a certain context and false in another context. Thus, hedges are regarded as "words whose job is to make things fuzzier or less fuzzy" (ibid:471). The expression of fuzziness can assist writers to avoid embarrassing situations and explain the writers' commitment to the true amount of statements, and it can also support them with more open path for the possibilities of interpretation (Salager-Meyer, 1994:ibid). On other hand, Crompton (1997:273) states that writers present their modesty for their achievements to avoid their personal involvement.

Second: to raise the precision or accuracy for writers' demands via the negotiation of the right exemplification of the state of knowledge under discussion. Thus, hedging as posted by Salager-Meyer (1994:151) possibly shows "the true state of the writers' understanding, namely, the strongest claims a careful researcher can make". Generally, the concept of hedging is utilized not only to present things fuzzy but also to negotiate for the best interpretation of understanding to give precision in scientific claims.

In another respect, Geyer (2008:57) confirms that hedging expressions are referred to as examples of politeness strategies. Likewise, Crompton (1997:274) asserts that hedging is a positive politeness strategy since it reflects positive attitude of the hearer. Whereas, Riekkinen (2009:43) mentions that hedging can be a kind of negative politeness as the writer or speaker gives the content of the utterance fuzzier instead of keeping its original meaning. To him (ibid) a criticism is an example of this kind by which the utterance is mitigated to become more acceptable to the reader or hearer.

\section{HEDGES IN THE WORLD OF DISCOURSE: PERSPECTIVE AND FUNCTION}

As mentioned earlier, hedges, metadiscourse, deal with knowledge about language beyond the word, clause, phrase and sentence that is needed for successful communication. It represents the patterns of language across texts and pays attention to the relationship between language users and the social and cultural context in which they use language. Metadiscourse also focuses on the way that the users of language show different attitudes of the world and different understandings. Here, the users of hedges are actually affected by social identities and relations. Hedges can also help us to show how identities and views of the world are established via the users. Hedges as metadiscourse deal with both spoken and written texts in respect to the users. (Brian Paltridge 2006:1-2).

However, Holmes (1995:74) believes that hedging devices are the dominant means to express positive politeness which is connected primarily with respect to other people's privacy being a central concept in English culture.

As has been said previously, hedges are regarded as mitigating devices which reduce the propositional content of the message. However, reduction can be done in various ways serving deferent linguistic and non-linguistic strategies. To express the functions of hedges clearly, the study needs to state these strategies as stated by Fraser (1996:167-183), as follows:

\section{Clausal Mitigators}

They are namely but-clauses and pseudoconditionals, usually taking the final position, i.e., after the propositional content. As positively polite devices, they reduce the illocutionary degree of the utterance via building upon face-preserving principles. This kind of linguistic marker "signal the speaker's desire to reduce the face loss associated with the basic message" (Fraser 1996:167). Thus, but-clauses serve to increase politeness by expressing agreement, or at least pseudoagreement. Leech (1983: 138) states "there is a tendency to exaggerate agreement with other people, and to mitigate disagreement by expressing regret, partial agreement, etc.". While Pseudoconditionals typically take the forms of if-clauses such as, "if I were you, if I may say so, if you like, if you wanted to, if you insist, if it comes to that, if that isn't an impertinent questions". This group is called pseudoconditionals because these if-clauses are not really conditional sentences in their nature since they syntactically miss the other part of the conditional structure and semantically they miss the condition which has to be achieved before something else can happen. Here, there is an attitude that the message is expressed in a more on-record way than is appropriate, and thus, there is a need to soften the content of the message by adding mitigation that would supply the intended compensation.

\section{Subjectivity Markers}

This category is represented by speaker-oriented markers. It emphasizes the subjective attitude of the speaker towards the message. For example, "I hope, I think, I suppose, I guess, I don't think, I wouldn't say, etc.". The function of this type of hedging is to attenuate the speaker's meaning by increasing the force of subjectivity of the utterance. Here, the addressee conveys an assertion into a question phrase, as Urbanova (1995:59) remarks, signals a lack of certainty and high degree of indeterminacy on the part of the speaker and consequently implies the necessity of confirmation on the part of the hearer". In this regard, hedges indicate to the hearer that the speaker's utterance is not to be regarded as something universally true or definite, but rather as a personal judgment, belief, opinion which is open to further dialogue or negotiation. 


\section{Downgraders}

They are considered non-imposing polite. If, however, this is not possible, then the imposition should be at least minimized. Downgraders, as speaker-orientated hedges, can be indicated by terms like "a bit, just, just in case, a little, a few, rather, scarcely, etc." These terms function to minimize the size of the imposition that is being made on the hearer. They function as a form of self-protection of the speaker, and this is because the lack of knowledge of the partner's belief, opinions or wants (ibid).

\section{Tentativizers}

Tentativizers are like subjective markers which give a huge degree of politeness by implying uncertainty, hesitation, or vagueness. This group consists of two types; they are (1) expressions such as "I don't know and well" which denote reservation and reduce the certainty and definitiveness of the utterance, and (2) the intentional vagueness, here, can be presented by terms like "sort of thing, a kind of" whose major purpose is to decrease explicitness of an utterance and enable the speakers to be less direct and bold on-record in conveying their meanings.

\section{Performative Hedges}

Leech (1983:139) mentions "Politeness is manifested not only in the content of conversation, but also in the way conversation is managed and structured by its participants", such as expressions like "I must ask, I (just) want to know, I'll (just) say one thing, I (just) wanted to apologize, I'm inclined to agree or I'm curious to know". These performatives hedges are speaker-orientated markers which merely comment on the speech acts that immediately follow, i.e., they are called "introductory". These hedges most frequently are face-threatening acts such as "apologies, requests, suggestions, etc". They participate towards a higher degree of politeness in different ways, i.e., they function as a linguistic means which indicates the speaker's illocutionary aim, giving the hearers time to shape and adjust their answers.

\section{METHODOLOGY}

\section{Corpus}

The corpus is based on the selection of 300 original Facebook comments taken randomly from online net. These comments are written by native speakers of English. These writers are gender-classified, as male and female, and divided into two groups in relation to their ages; the first group consists of female users ranging from age 25 to 35 while the second group consists of female users from 35 to 55 . The same strategy is followed with male users.

\section{Model}

The study adopts Hyland 's model (2005). Abdi, (2011:34) claims that this model is highly preferred in modern metadiscourse studies for being comprehensive, up-to-date, simple and clear. Thus, in the analysis phase, Hyland's (2005) categories of hedges are utilized; they are: model auxiliaries, introductory verbs, adjectives, adverbs and nouns. These categories are analyzed in terms of the study variables of sex and age.

\section{Data Analysis}

\section{Modal auxiliaries}

In the analysis of model auxiliaries, a group of words are focused. This group includes "can, could, may, might, must, should, will and would" as modal auxiliaries because these modals create hedged meaning (Hyland, 2005: 132). Hyland (1998:349) states that with the modal auxiliary 'will', as being a hedging device, can be, to an extent, problematic because it can often be used as an expression of futurity and also as an indication of epistemic modality (predictability meaning). Moreover, according to Coates (1983:179), the "Occurrences of 'will', with future reference, commonly involve a component of uncertainty,". This is because it denotes future which "inevitably involves some uncertainty or doubt" (Hyland,1998:116). However, the study confine itself to those examples of 'will' that denote 'definite uncertainty' and not those of 'futurity'. Hyland (ibid) and Hinkel (2009:54) share the same view point that the use of modal auxiliaries such as 'can, may, might, could' may function a wide-range purpose in written academic discourse. To them, these verbs, with other linguistic elements, serve a range of pragmatic and textual functions. They often indicate likelihood, possibility, evidentness, politeness and strategic vagueness in discourse. In the social media Facebook comments, the writers utilize such modals to refer to matters of personal beliefs and knowledge which function as a basis for writers to put forth their stances or judgments about states of affairs, events, and actions. These auxiliaries show markers of possibility and tend to have overlapping meanings that can be changed in some contexts. To Hyland (2000:XI), writing should include "a sense of purposiveness, stance, belonging and a sense of personal identity". Thus, Facebook, as a medium, must be interactive and this interaction is not a stable-1 process of encoding and decoding, but instead, it reflects social reality, i.e. the use of such type of text is effected by the age of the writers and their gender. Therefore, Facebook is an interactive, and cognitive project in which users can give their stances through their writings. In this respect, the users, here, try to modulate their statements to support their stances. In fact, the users use modal auxiliaries to enhance their stances in their writings (Varttala, 2001:61).

Table 1. The distribution of model auxiliaries

\begin{tabular}{lcccc}
\hline Sex \& age & Female (25-35 Y) & Female (35-55Y) & Male (25-35 Y) & Male (35-55Y) \\
Hedges & 71 & 83 & 39 & 54 \\
Modal auxiliaries & 23.66 & 27.66 & 13 & 18 \\
\hline
\end{tabular}


Additionally, the use of 'should', for example aims at conveying politeness and vagueness to avoid smashing between writers and readers (Salager-Meyer, 1994:153).

The distribution of the use of model auxiliaries in the sample of the study is tabulated as follows:

\section{Introductory verbs}

Introductory verbs are words in a sentence that indicate an action, a state of being, or possession. In English, these verbs take three general forms: the infinitive form, the base form, and the conjugated form. Sometimes the verb denotes what or who is doing the action though usually English needs a subject in order to determine what or who is doing the action (Rodney \& Decker,2013:1-3).

In other words, Hyland (1998:120) states that these verbs "perform, rather than describe the acts." Such as the verbs claim, propose, suggest and imply, are examples of this case. Another group is tentative Cognition Verbs. They refer to "the mental status or processes of those whose views are reported rather than to linguistic activity," (Varttala,2001:122). The third group is tentative Linking Verbs, such as appear, seem and tend. These verbs express tentativeness concerning "the ideas put forth by the authors,"(ibid:123).

Introductory verbs are used in only 264 comments of the study sample. Hence, 36 comments are void of any introductory verbs. The following table- 2 shows how the sample of the study use introductory verbs.

\section{Adjectives}

As regard adjectives, Varttala $(2001: 125)$ points out that some adjectives can be used to indicate tentative, uncertain and not quite precise characteristics of nouns or actions. In fact, these adjectives indicate probability. They are known as adjectives of Indefinite degree, adjectives of Indefinite frequency and approximative adjectives. For probability adjectives, there are words like probable, plausible, potential, suggestive, etc. These adjectives, in fact, denote different degrees of probability concerning the certainty or accuracy of what is being said. The second type of adjectives is related to indefinite frequency; they explain tentative quantifications where it is not exactly necessary or possible to quantify the phenomenon. For examples, the words common, frequent, rare, popular, typical, etc. The third type of adjectives is of indefinite degree, here, as Varttala (ibid:137) remarks, the writers can "invest the information presented with the degree of certainty", for examples words like, little, main, relative, small, fair, large, significant, slight, substantial, etc. The last type is approximative adjectives such as close, just, gross, approximate and virtual. All these types of adjectives help writers "draw attention to the approximate nature of the information presented."

The following table-3 shows the distribution of adjectives as used by the study sample.

\section{Adverbs}

Here, the categories of adverbs are the same as adjectives; they are classified into adverbs of probability, of indefinite frequency, of indefinite degree and of approximative. Varttala (ibid:139) and Hyland (1998:122) share the same view point that these types or categories indicate the potential meaning rather than their syntactic aspects when they are used as hedging devices. In the first type of probability adverbs, according to Quirk, et al., (1985:620), they denote some "degree of doubt" such as perhaps, possible, likely, potentially, probably, tentatively, seemingly, etc. The second type of adverbs includes words like occasionally, frequently, seldom, usually, often, sometimes, etc.; they indicate inherent indefiniteness in the meaning conveyed. While the third type, as stated by Quirk et al., (ibid:598-9), consists of those adverbs that "seek to express only part of the potential force of the item concerned", for instance, fairly, slightly, considerably, greatly, largely, partly, mostly, relatively, significant$l y$, etc. The last type is adverbs of approximative. It includes those words that "express an approximation to the force of the verb", for instance, almost, just, about, approximately, closely, around, nearly, roughly, nearly, etc.

In fact, the main function of utilizing hedges of adverbs by the writers is to open a relationship and go on through dialogue with others away from any restriction or commitment.

The following table- 4 reveals the distribution of adverbs that are used by the study sample.

\section{Nouns}

There is a number of nouns with potential hedging meanings. To Varttala (2001: 141) and Hyland (1998:123), there

Table 2. The distribution of introductory verbs

\begin{tabular}{lcccc}
\hline Sex \& age & Female (25-35 Y) & Female (35-55Y) & Male (25-35 Y) & Male (35-55 Y) \\
\hline Introductory verbs & 64 & 75 & 21 & 29 \\
Percentage & 33.86 & 39.68 & 11.11 & 15.34 \\
\hline
\end{tabular}

Table 3. The distribution of adjectives

\begin{tabular}{lcccc}
\hline Sex \& age & Female (25-35 Y) & Female (35-55Y) & Male (25-35 Y) & Male (35-55 Y) \\
\hline Adjectives & 78 & 84 & 43 & 57 \\
Percentage & 29.77 & 32.06 & 16.41 & 21.75 \\
\hline
\end{tabular}


Table 4. The distribution of adverbs

\begin{tabular}{lcccc}
\hline Sex \& age & Female (25-35 Y) & Female (35-55Y) & Male (25-35 Y) & Male (35-55 Y) \\
Hedges & 58 & 71 & 51 & 56 \\
Percentage & 24.57 & 30.08 & 21.61 & 23.72 \\
\hline
\end{tabular}

Table 5. The distribution of nouns

\begin{tabular}{|c|c|c|c|c|}
\hline Hedges Sex \& age & Female $(25-35$ Y) & Female (35-55Y) & Male (25-35 Y) & Male (35-55 Y) \\
\hline Nouns & 28 & 34 & 13 & 19 \\
\hline Percentage & 29.78 & 36.17 & 13.82 & 20.21 \\
\hline
\end{tabular}

Table 6. Overall distribution of hedges categories

\begin{tabular}{|c|c|c|c|c|c|c|c|c|}
\hline$\overbrace{\text { Hedges }}^{\text {Sex \& age }}$ & $\begin{array}{c}\text { Female } \\
(25-35 \text { Y) }\end{array}$ & Percentage & $\begin{array}{c}\text { Female } \\
(35-55 Y)\end{array}$ & Percentage & $\begin{array}{c}\text { Male } \\
(25-35 \text { Y) }\end{array}$ & Percentage & $\begin{array}{c}\text { Male } \\
(35-55 \mathrm{Y})\end{array}$ & Percentage \\
\hline Modal auxiliaries & 71 & 23.66 & 83 & 27.66 & 39 & 13 & 54 & 18 \\
\hline Introductory verbs & 64 & 33.86 & 75 & 39.68 & 21 & 11.11 & 29 & 15.34 \\
\hline Adjectives & 78 & 29.77 & 84 & 32.06 & 43 & 16.41 & 57 & 21.75 \\
\hline Adverbs & 58 & 24.57 & 71 & 30.08 & 51 & 21.61 & 56 & 23.72 \\
\hline Nouns & 28 & 29.78 & 34 & 36.17 & 13 & 13.82 & 19 & 20.21 \\
\hline Total & 299 & & 347 & & 167 & & 215 & \\
\hline
\end{tabular}

are three major kinds of nouns; they are a) non-factive assertive nouns such as assertion, implication, claim, argument, proposition, prediction, suggestion, proposition, etc., b) tentative cognition nouns such as belief, estimation, assumption, notion, view, interpretation, inference, etc. and c) nouns of tentative Likelihood like possibility, probability, chance, likelihood, opportunity, etc.

Although, nouns are less used by the writers in their texts but this does not reject the fact that the writers use this type of hedging as they detachedly want others to know that they do not claim to have the final word on the subject; they prefer to continue talking with others freely, i.e., to open a dialogue and avoid commitment in their discourse.

The following table-5 manifests the distribution of nouns as hedging devices by the study sample.

\section{FINDINGS AND DISCUSSION}

After analyzing the data regarding the categories adopted in this study, it is possible to group them altogether in one table -6 as follows:

It is evident that the above table reveals the superiority of female over male users of Facebook in the area of hedging. Both groups of female users manifest the large-scale utilization of hedges in their writing. Female users utilize hedges in their writing for the purpose of showing femininity and womanliness which totally lead to politeness, while male users manifest the low- scale of hedges in their writing. This inclination supports the idea developed by Crompton (1997:274) and Lakoff (1975:57) that hedging can serve positive politeness in social media in contrast to Riekkinen (2009:43) who considers it as a negative one.
One of the important ideas in the findings of the study is that hedging, to a large extent, is connected to age. The more aged the writers are, the more use of hedges they do.

The findings points out essential differences in terms of the use of hedging terms. As mentioned earlier, spoken language suggests that females use hedging in a variety of ways more than males do. Thus, the study agrees with Lakoff, (1975) and Robson \& Stockwell (2005) who argue that the texts produced by females seem to be more hedged than the text produced by males. More clearly, hedging are the favored forms of spoken and written language that are highly used by females. This is because females seek low commitments in their discourse, they release themselves from the commitments or restriction more than males do. This leads the study to admit that hedging is mostly an indicator of femininity.

The findings also reveal that these writers seem to show their gender identities by their marked preferences for hedging. In this respect, Litosseliti's (2006:3) believes that "our gender identities (sense of who we are as gendered subjects) are largely constructed through the discourses we inhabit and negotiate". In line with, the study comes to agree with Holmes \& Meyerhoff's statement (2005:56); that "texts are examined for what they reveal not about the author's gender but about the author's assumptions, about gender or more accurately, about the representation of gender that text offers up".

\section{CONCLUSIONS}

1. There are fundamental contrasts with respect to sex and age in relation to the use of hedging. Females use hedges more than males do in their writings and the more one 
grows older in age, the more use of hedges s/he does, i.e., hedging increases as far as the writer is older.

2. The use of different kinds of hedges vary from male to female, for instance, auxiliary verbs are used more by male users, introductory verbs, nouns, adjectives and adverbs are used more by females.

3. Hedges are used as markers of womanliness and politeness.

4. All types of hedging are used by the writers to enable them open conversations or dialogues and get rid of any commitment, i.e. they like to open a relationship as possible as they can with others.

4. Gender identity can sometimes be manifested through the use of hedging. Writers frequently tend to show their identity through what they write. And their writing reveals their gender-based preferences.

\section{REFERENCES}

Bazerman, C. (1988). Shaping Written Knowledge. Wisconsin: Wisconsin University Press.

Bonyadi, A., Gholami, J., \& Nasiri, S. (2012). A contrastive study of hedging in Environmental Sciences research articles. Journal of Language Teaching and Research, 3(6), 1186-1193.

Bruce, I. (2005). Syllabus Design for General EAP Courses: a Cognitive Approach. Journal of English for Academic Purposes. 4(3), 239-256.

Coates, J. 2004. Women, Men and Language: A sociolinguistic account of gender in language. (third edition) Edinburgh: Longman.

Crompton, P. (1997). Hedging in academic writing: Some theoretical problems. English for Specific Purposes, 16(4), 271-287.

Fraser, B. (1996). "Pragmatic markers". Pragmatics 6.2 (1996): 167-190.

Gillaerts, P., \& Van de Velde, F. (2010). Interactional Metadiscourse in Research Article Abstracts. Journal of English for Academic Purposes. 9(2), 128-139.

Geyer, N. (2008). Discourse and Politeness: Ambivalent Face in Japanese. New York: Continuum.

Hewings, M. (2006). Introduction. In M. Hewings (Ed.). Academic writing in context: Implications and applications (pp. 79-92). London: Continuum.

Holmes,J.(1984).Modifying Illocutionary Force. Journal of Pragmatics, 8, 345-365.

---------. (1995). Women, Men and Politeness. New York: Longman.

----------. \& Meyerhoff, M. (2005). The Handbook of Language and Gender. Blackwell Publishing.

Hyland, K. (1998). Hedging in Scientific Research Articles. Amsterdam: John Benjamins.
(2000). Disciplinary Discourses: Social Interaction in Academic Writing. London: Pearson Education Ltd. - \& Tse, P. (2004). Metadiscourse in Academic Writing: A Reappraisal. In Applied Linguistics, 25(2), 156-177. -. (2005). Metadiscourse: Exploring interaction in writing. Continuum: London.

Lakoff, G. (1975). Language and Women's Place. New York: Harper Colophon Books.

Leech, G. (1983). Principles of Pragmatics. New York: Longman.

Litosseliti, L. (2006). Gender and Language. London: Hodder Arnold.

Newman, M. L., Groom, C. J., Handelman, L. D., \& Pennebaker, J. W. (2008). Gender differences in language use: An analysis of 14,000 text samples. Discourse Processes, 45, 211-236.

Paltridge, B.(2006). Discourse Analysis. London \& New York: Longman

Peterlin, A. P. (2005). Text-Organizing Metatext in Research Articles: An English-Slovene Contrastive analysis. English for Specific Purposes. 24, 307-319.

Quirk, R., Greenbaum, S., Leech, G., \& Svartvik, J. (1985). A Comprehensive Grammar of the English Language. London \& New York: Longman.

Riekkinen, N. (2009). Softening Criticism: The Use of Lexical Hedges in Academic Spoken Interaction (Pro Gradu Thesis). Retrieved August, 3 ${ }^{\text {rd }}$, 2013, from http://www. helsinki.fi/englanti/elfa/ProGradu_Niina_Riekkinen.pdf

Rounds, P. (1982). Hedging in Written Academic Discourse: Precision and Flexibility. University of Michigan: Mimeo.

Robson, M.,\& Stockwell, P. (2005). Language in Theory: A Resource Book for Students: ABCD. London \& New York: Rutledge.

Rodney, J. \& Decker, Th.D. (2013). Introduction to Verbs. London: Longman.

Tannen, D. (1990). You just don't understand: Women and Men in Conversation. New York: William Morrow.

Varttala, T. (2001). Hedging in Scientifically Oriented Discourses: Exploring variation According to Discipline and Intended Audience (Electronic Doctoral Dissertation. Acta Electronica Universitatis Tamperensis 138). Retrieved from http://acta.uta.fi/pdf/951-44-5195-3. pdf.

Urbanová, L. (1995). On the Status of Declarative Questions in English Conversation". Brno Studies in English 21 (1995): 59-65.

Weatherall, A. (2002). Gender, Language, and Discourse. London: Routledge.

Xiaofang Gao, X. (2004). Contrastive Analysis of Hedges in a Sample of Chinese and English Molecular Biology Papers. Psychological Reports, (95),487-493. 